\title{
Successful transfer of the embryos of Przewalski's horses (Equus przewalskii) and Grant's zebra (E. burchelli) to domestic mares (E. caballus)
}

\author{
P. M. Summers, A. M. Shephard, J. K. Hodges, J. Kydd*, M. S. Boyle* and \\ W. R. Allen*
}

$M R C / A F R C$ Comparative Physiology Research Group, The Institute of Zoology, The Zoological Society of London, Regent's Park, London NWI 4RY, and *Thoroughbred Breeders' Association Equine Fertility Unit, Animal Research Station, 307 Huntingdon Road, Cambridge CB3 OJQ, U.K.

\begin{abstract}
Summary. Blastocysts were collected non-surgically from 2 Przewalski's horse and 2 Grant's zebra mares and transferred extra-specifically to domestic horse and donkey recipients. Nine Przewalski's horse embryos were transferred surgically, and 2 nonsurgically, to domestic Welsh-type pony mares. After surgical transfer, $7(\mathbf{7 7} \cdot \mathbf{8 \%})$ pregnancies were established and 4 foals were born. Twelve Grant's zebra embryos were transferred surgically to 5 pony and 7 domestic donkey recipients respectively and 1 non-surgically to a donkey; $3(60 \%)$ zebra-in-horse pregnancies were established and 2 went to term. Only $2(28 \cdot 6 \%)$ zebra-in-donkey pregnancies were established but neither went to term, although one zebra foal was aborted alive at Day 292 but failed to survive. No pregnancies resulted from the non-surgical transfers. Measurement of chorionic gonadotrophin concentrations and parental-specific lymphocytotoxic antibodies in the serum of the recipient animals indicated a pronounced maternal immunological response to the extra-specific embryo, but this could not be correlated with success or failure of pregnancy.

The results indicate that extra-specific embryo transfer may be a useful aid to breeding exotic equids in captivity.
\end{abstract}

\section{Introduction}

Consideration has been given in recent years to applying the newer technologies in domestic animal breeding towards improving the fecundity of endangered exotic species (Durrant \& Benirschke, 1981; Stover \& Westrom, 1984). Embryo transfer is one such technique, although two major obstacles limit its application to exotic species. First, knowledge of the reproductive physiology of many exotic species is limited, and embryo transfer can only reasonably be carried out for those species for which adequate information exists or can be extrapolated from closely related domestic species. Second, the fact that a species is endangered means that there is limited potential for intra-specific embryo transfer. Surrogate mothers therefore need to be selected from closely related domestic or non-endangered exotic species.

An embryo transferred extra-specifically needs to overcome several major hurdles if it is to survive to term, such as triggering the necessary maternal recognition of pregnancy signal to prevent cyclic regression of the corpus luteum (Short, 1969) and abrogating any maternal cytotoxic response that may be elicited against its xeno-antigens (Billingham \& Head, 1981). Problems of this type are likely to be reduced in magnitude when selecting a surrogate species that hybridizes naturally with the embryo donor species. Cross-species hybridization is a particular feature of the genus Equus (King, 1965; Gray, 1972; Short, 1975) and, furthermore, successful extra-specific pregnancy between domestic horses and donkeys has already been demonstrated (Allen, 1982). 
The present studies were undertaken to examine the techniques of embryo collection from Przewalski's or Mongolian wild horse (Equus przewalskii) and Grant's variety of the common zebra (E. burchelli), and to study the immunological and endocrinological features of extra-specific pregnancies created by transferring these embryos to domestic horses and donkeys. Przewalski's horse is extinct in the wild and is now confined to zoological parks and wildlife reserves throughout the world. Grant's zebra is not endangered but was chosen as a model for the endangered zebra species.

\section{Materials and Methods}

Animals. Two 6-year-old maiden Przewalski's horse mares and two multiparous Grant's zebra mares (10 years old and 11 years old respectively) were used as donors. They were housed at London Zoo, Regent's Park, along with a stallion of each species. The experiments were conducted during April to September inclusive in 1983 and 1984. Recipient pony mares (Welsh Mountain, Welsh Cob and New Forest cross) and English-type jenny donkeys of various ages and parity were maintained at the Animal Research Station, Cambridge. The diploid chromosome numbers of the animals used were $2 n=66$ for the Przewalski's horse, $2 n=46$ for the Grant's zebra, $2 n=64$ for the domestic mare and $2 n=62$ for the domestic donkey. Donor mares were placed with their respective stallions for at least $1 \mathrm{~h}$ daily during the period when they were expected to be in oestrus and observed for behavioural signs and mating: ovulation was presumed to have occurred on the last day of oestrus (Day 0). Oestrus in recipients was detected by daily teasing with a pony stallion or jack donkey and ovulation was determined by radioimmunoassay of progesterone concentration in peripheral plasma samples recovered daily during oestrus and for 3 days afterwards; Day 0 was taken as the day before plasma progesterone concentrations rose to $>1 \mathrm{ng} / \mathrm{ml}$.

Embryo recovery and transfer. Embryos were recovered non-surgically on Days 6-10, usually Day 7 or 8, and transferred either surgically ( 21 embryos) or non-surgically ( 3 embryos) to recipients that had ovulated $1-3$ days after the respective donor, as described previously by Kydd et al. (1985). Embryos were transported from London to Cambridge by car, suspended in $3.0 \mathrm{ml}$ fresh flushing medium supplemented with $20 \%$ fetal calf serum in a conical plastic test tube held in the driver's breast pocket; the interval between recovery and transfer of the embryos ranged from 2.5 to $4.5 \mathrm{~h}$. The donor mares were short-cycled and re-mated throughout the two breeding seasons by inducing premature luteolysis with a single intramuscular injection $(373$ or $500 \mu \mathrm{g}$ ) of the prostaglandin analogue, cloprostenol (Estrumate: ICI Pharmaceutical Division, Cheshire, U.K.) given immediately after each embryo collection attempt.

Pregnancy was diagnosed and monitored by real-time ultrasound examination of the uterus (Simpson et al., 1982), beginning at Day 16-20 after ovulation and continuing at approximately weekly intervals thereafter to Day 120 . In addition, samples of peripheral blood $(25 \mathrm{ml})$ were recovered 3 times each week from the jugular vein of each pregnant recipient between Days 20 and 120, for assay of plasma progesterone and serum chorionic gonadotrophin (CG) concentrations, and for the detection of cytotoxic antibodies against lymphocytes from the genetic parents (sire and dam) of the conceptus. The two zebra mares were allowed to remain pregnant at the end of the 1984 breeding season. Peripheral blood was also collected from them at 8-10 day intervals between Days 32 and 120 of gestation for assay of CG concentrations.

CG assay. CG concentrations in serum were measured by haemagglutination-inhibition assay as described by Allen (1969a), using a rabbit anti-horse CG serum (MSIIB) raised against highly purified horse CG (MSII, 16000 i.u./mg; Dr M. J. Stewart, Cambridge). This antibody cross-reacted strongly with purified donkey CG (Aggarwal et al., 1980) and produced parallel dose-response curves against pregnant horse, donkey and zebra serum in the haemagglutination-inhibition assay and in a double-antibody radioimmunoassay for horse LH (Urwin \& Allen, 1982). The Second International Standard for Mare Serum Gonadotrophin (2nd IRP-PMSG; Bangham \& Woodward, 1966) was used as standard and the limit of sensitivity of the assay was $0.5 \mathrm{i} . \mathrm{u}$. horse $\mathrm{CG} / \mathrm{ml}$ serum.

Progesterone assay. Plasma progesterone concentrations were measured by radioimmunoassay as described by Newcomb et al. (1977) using an antiserum prepared in a goat against progesterone-1 $1 \alpha$ succinyl-bovine serum albumin conjugate (No. 465/7: Specific Antisera Ltd, Cheshire, U.K.) and $\left[1,2,6,7,(\mathrm{n}) \cdot{ }^{3} \mathrm{H}\right]$ progesterone (TRK413; sp.act. $8 \mathrm{I} \mathrm{Ci} / \mathrm{mmol}$ : Radiochemical Centre, Amersham, U.K.) as label. Plasma aliquants $(20 \mu \mathrm{l})$ were assayed unextracted and the limit of sensitivity of the assay was $0.5 \mathrm{ng}$ progesterone/ml plasma. The intra- and inter-assay coefficients of variation were 6.4 and $6.7 \%$ respectively.

Lymphocytotoxic assay. The standard NIH lymphocyte microcytoxicity dye-exclusion test, as modified for use with horse lymphocytes by Bright $e t$ al. (1978), was used to screen sera from recipients for the presence of humoral antibodies directed against Class I major histocompatibility (MHC) antigens of the genetic parents of the conceptus. Peripheral blood lymphocytes (PBL) were isolated from samples of peripheral blood recovered from the 3 zebra and 3 Przewalski's horse parent donors by centrifugation over a density gradient interface (Ficoll Hypaque; $1.077 \mathrm{~g} / \mathrm{ml}$ : Pharmacia, Uppsala, Sweden). Aliquants of test serum $(1 \mu \mathrm{l})$ and a suspension of $2 \times 10^{6} \mathrm{PBL} / \mathrm{ml}(1 \mu \mathrm{l})$ were incubated for $30 \mathrm{~min}$ at room temperature under oil in a well of a microtitre plate before adding $5 \mu$ rabbit complement (Buxted Rabbit Co., Sussex, U.K.) for a further $1 \mathrm{~h}$. The cells were then stained by adding $2 \mu \mathrm{l}$ of a $5 \%$ (w:v) solution of eosin dye (Raymond A. Lamb, London) before being fixed by a final solution of $5 \mu \mathrm{l}$ of $37 \%$ formalin, $\mathrm{pH} 7.0$ (Kydd et al., 1982). 


\section{Results}

\section{Embryo collection and transfer}

Eleven embryos were recovered from 18 collection attempts $(61 \%)$ on the 2 Przewalski's horse mares and 14 embryos were recovered from 25 collection attempts $(56 \%)$ on the 2 zebra mares. The embryos from these exotic equids morphologically resembled those of the domestic horse (Betteridge et al., 1982), and ranged from early blastocysts (Day 6 and some Day 7) to expanded blastocysts (Day 8 and 10; Table 1). All the embryos except one appeared intact and normal immediately after collection, and they did not undergo any structural changes during the interval from collection to transfer. One Day-8 zebra blastocyst was partly collapsed, had several cracks in the zona pellucida and appeared to contain a number of degenerate cells; a pregnancy did not result from its transfer. The zona pellucida was still present on the Day- 6 and 4 of the 13 Day- 7 embryos but the remaining embryos had hatched from the zona and were enveloped by a thin acellular capsule as described for horse embryos by Betteridge et al. (1982).

The outcome of the embryo transfer is summarized in Table 2. Failure to establish, or the subsequent loss, of a pregnancy was not related to the degree of synchrony between donors and

Table 1. Relationship between stage of recovery and diameter of Przewalski's horse and Grant's zebra embryos

\begin{tabular}{|c|c|c|c|c|c|c|}
\hline \multirow{2}{*}{$\begin{array}{l}\text { Day of } \\
\text { collection* }\end{array}$} & \multicolumn{2}{|c|}{ No. of embryos } & \multicolumn{4}{|c|}{$\begin{array}{l}\text { Mean } \pm \text { s.e.m. (range) } \\
\text { of embryo diam. (mm) }\end{array}$} \\
\hline & Przewalski & Zebra & Prze & valski & $\mathrm{Zel}$ & bra \\
\hline 6 & & 1 & & & $0 \cdot 1$ & 84 \\
\hline 7 & 6 & 7 & $0.29 \pm 0.05$ & $(0 \cdot 14 \quad 0 \cdot 48)$ & $0.26 \pm 0.07$ & $(0 \cdot 17-0 \cdot 70)$ \\
\hline 8 & 4 & 6 & $0 \cdot 58 \pm 0.20$ & $(0 \cdot 23-1 \cdot 16)$ & $1 \cdot 30 \pm 0.391$ & $(0 \cdot 32-2 \cdot 96)$ \\
\hline 10 & 1 & & & 0 & & \\
\hline
\end{tabular}

*Day $0=$ presumed day of ovulation.

Table 2. Pregnancy rates after the transfer of Przewalski's horse and Grant's zebra embryos to domestic horse and donkey recipients

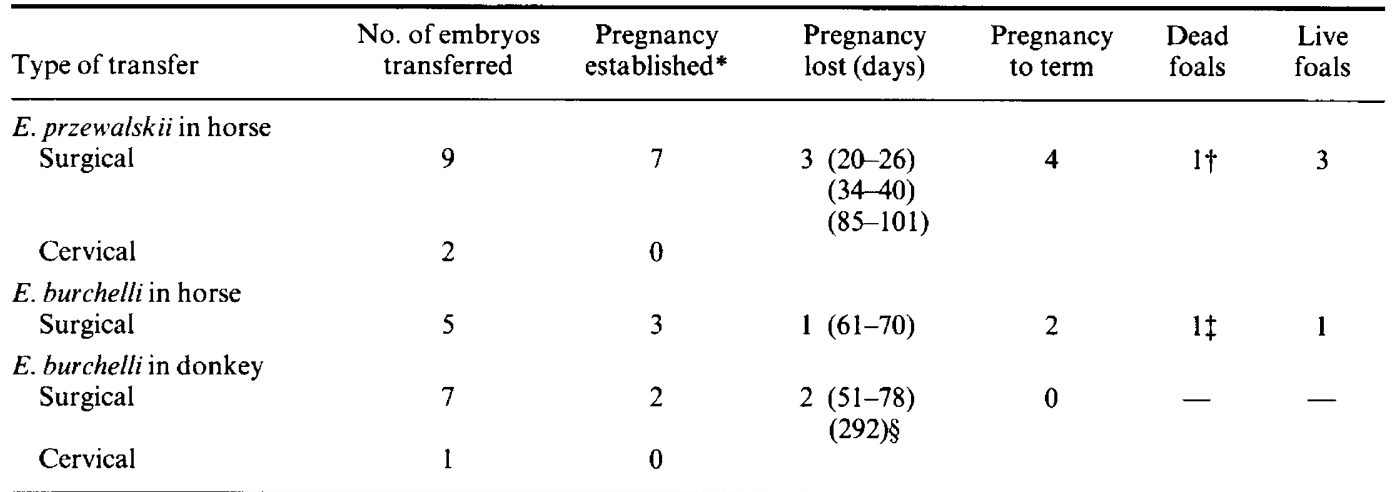

* Recipients in which a conceptus could be detected by ultrasound examination of the uterus on Days 16-20 were classified as having a pregnancy established.

†Unruptured amnion.

$\ddagger$ Toxaemia (Day 350 ).

$\S$ Toxaemia (Day 292). 
Table 3. Chorionic gonadotrophin (CG) secretion patterns exhibited by mares, donkeys and zebras carrying extra- and intra-specific conceptuses

\begin{tabular}{lcccl}
\hline $\begin{array}{l}\text { Type of } \\
\text { pregnancy }\end{array}$ & Recipient & $\begin{array}{c}\text { Period when } \\
\text { CG present } \\
\text { (days after } \\
\text { ovulation) }\end{array}$ & $\begin{array}{c}\text { Peak CG } \\
\text { conc. } \\
\text { measured } \\
\text { in serum } \\
\text { (i.u./ml) }\end{array}$ & \multicolumn{1}{c}{$\begin{array}{c}\text { Outcome of } \\
\text { pregnancy }\end{array}$} \\
\hline $\begin{array}{l}\text { Przewalski's } \\
\text { horse-in-horse }\end{array}$ & HP & $38-80$ & 70 & Live foal, Day 329 \\
& KH & $40-55$ & 5 & Live foal, Day 324 \\
& MQ & $40-82$ & 33 & Resorbed, Day 85-101 \\
& MN & $35-95$ & 135 & Live foal, Day 322 \\
& TM & $44-70$ & 4 & Live foal, Day 334 \\
Zebra-in-horse & KS & $36-45$ & $0 \cdot 5$ & Resorbed, Day 61-70 \\
& MG & 37 & $0 \cdot 5$ & Live foal, Day 367 \\
Zebra-in-donkey & MR & $40-56$ & $1 \cdot 5$ & Foal stillborn, Day 350 \\
& UM & $39-83$ & 22 & Aborted, Day 292 \\
Zebra-in-zebra & PF & $40-59$ & 7 & Resorbed, Day 53-79 \\
& NJ & $39-108$ & 9 & Live foal, Day 364 \\
& J & $38-115^{*}$ & 28 & Live foal, Day 355 \\
\hline
\end{tabular}

${ }^{*}$ Last day on which a blood sample was taken.

recipients, the age of the embryo or the interval between embryo collection and transfer. Of the 7 Przewalski's horse-in-horse pregnancies established, 4 were carried to term and resulted in the birth of 4 live foals ( 1 colt and 3 fillies) after gestation lengths of 322-334 days (Table 3). One mare gave birth unattended in the field and the well-developed filly foal was suffocated by the unruptured amnion. The other 3 foals were born spontaneously under supervision and were successfully reared by their surrogate mothers.

Two zebra filly foals (Fig. 1) were born (one stillborn) from 3 established zebra-in-horse pregnancies after gestation periods of 350 and 367 days. The mare in which the well-developed filly zebra foal was stillborn at Day 350 had shown increasing abdominal discomfort and non-infective polyarthritis during the 3-week period before foaling. These and other clinical signs suggested some form of immunologically-based pregnancy toxaemia syndrome. The foal died in utero during a protracted first-stage labour and was removed by Caesarian section. One zebra-in-donkey pregnancy was carried to Day 292 when the foal was aborted alive, but it survived for only $3 \mathrm{~h}$. This recipient jenny donkey also showed acute painful polyarthritis for 4 days before abortion.

\section{Production of chorionic gonadotrophin}

As shown in Table 3, Przewalski's horse-in-horse pregnancies were characterized by CG secretion profiles similar to those measured in normal, intra-species horse-in-horse pregnancies (Allen, 1969 b), but with considerable variation between the 4 animals, both in peak CG concentrations and in the time of disappearance of CG activity from the serum. In contrast, minimal amounts of $\mathrm{CG}$, at the limits of the sensitivity of the assay method, were detected for an abnormally brief period of gestation (Days 36-56; Table 3) in the serum of the 3 mares carrying zebra conceptuses.

Both of the intra-specific zebra-in-zebra pregnancies (Table 3) exhibited long flat profiles of $\mathrm{CG}$, with peak serum concentrations ( 9 and $28 \mathrm{i} . \mathrm{u} . / \mathrm{ml})$, and the duration of secretion of hormones (to Day 108 and in excess of Day 115 respectively) being reminiscent of the gonadotrophin profiles seen in donkeys carrying intra-species donkey conceptuses (Allen, 1975). Similar peak serum CG concentrations were measured in the 2 donkeys carrying zebra conceptuses in the present experiment 

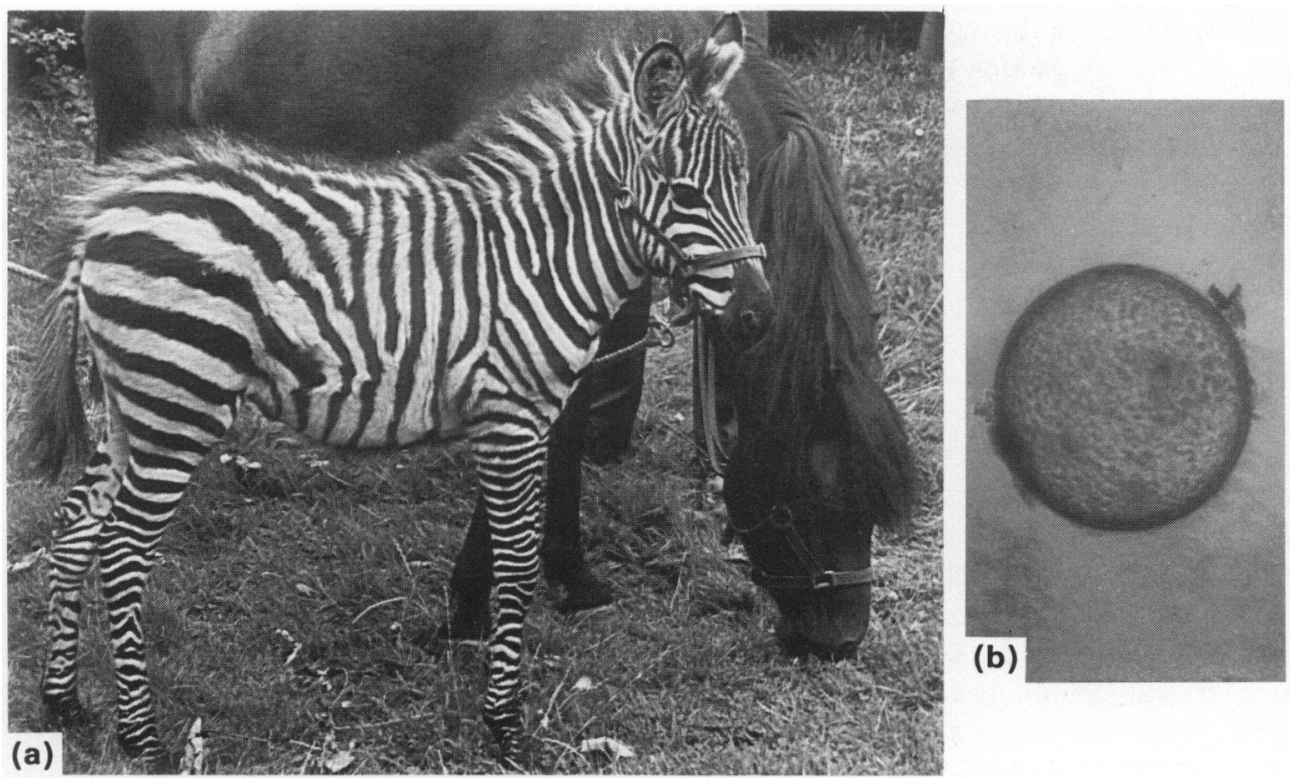

Fig. 1. Filly foal (a) born after the transfer of a Day-8 zebra expanded blastocyst (b) to a surrogate pure Welsh pony mare.

Table 4. Development of lymphocytotoxic antibodies in horse and donkey recipients carrying either Przewalski's horse or zebra extra-specific conceptuses

\begin{tabular}{|c|c|c|c|c|c|}
\hline $\begin{array}{l}\text { Type of } \\
\text { pregnancy }\end{array}$ & Recipient & $\begin{array}{l}\text { Period during } \\
\text { which sera } \\
\text { tested for } \\
\text { antibody* }\end{array}$ & $\begin{array}{l}\text { Antibody } \\
\text { present } \\
\text { against } \\
\text { sire* }\end{array}$ & $\begin{array}{l}\text { Antibody } \\
\text { present } \\
\text { against } \\
\text { dam* }\end{array}$ & Outcome of pregnancy \\
\hline $\begin{array}{l}\text { Przewalski's } \\
\text { horse-in-horse }\end{array}$ & $\begin{array}{l}\text { HP } \\
\text { KH } \\
\text { MQ } \\
\text { MN } \\
\text { TM }\end{array}$ & $\begin{array}{l}18-194 \\
14-134 \\
20-128 \\
19-68 \\
21-70\end{array}$ & $\begin{array}{l}- \\
33-134 \\
41-128 \\
40-68 \\
56-70\end{array}$ & $\begin{array}{l}33-134 \\
34-128 \\
40-68 \\
21-70\end{array}$ & $\begin{array}{l}\text { Live foal, Day } 329 \\
\text { Live foal, Day } 324 \\
\text { Resorbed, Day } 85-101 \\
\text { Live foal, Day } 322 \\
\text { Live foal, Day } 334\end{array}$ \\
\hline Zebra-in-horse & $\begin{array}{l}\mathrm{KS} \\
\mathrm{MG} \\
\mathrm{MR}\end{array}$ & $\begin{aligned} 14-69 \\
4-181 \\
21-139\end{aligned}$ & $\begin{array}{l}43-69 \\
46-181 \\
49-99\end{array}$ & $\begin{array}{l}43-69 \\
46-181 \\
35-128\end{array}$ & $\begin{array}{l}\text { Resorbed, Day } 61-70 \\
\text { Live foal, Day } 367 \\
\text { Foal stillborn, Day } 350\end{array}$ \\
\hline Zebra-in-donkey & UM & $18-188$ & $48-158$ & $48-168$ & Aborted, Day 292 \\
\hline
\end{tabular}

*Days after ovulation in recipients.

(7 and 22 i.u./ml respectively). However, CG disappeared from the serum much earlier in gestation (Days 59 and 83 respectively).

There was no correlation between the success or failure of the extra-species pregnancies and the CG profiles exhibited by the surrogate mothers.

\section{Lymphocytotoxic antibodies}

Except in one of the Przewalski's horse-in-horse pregnancies (Mare HP), a strong cytotoxic antibody response to lymphocytes of the genetic parents of the transferred embryo was measured in the peripheral serum of the 8 recipient mares and one recipient donkey tested (Table 4 ). Generally, 
antibodies were first detected soon after the time when endometrial cup development would have begun on Day 36. In one recipient (Mare $\mathrm{KH}$ ), however, antibodies against the lymphocytes of both the sire and dam appeared at Day 33 and in another recipient (Mare TM), antibodies against the dam, but not the sire, of the embryo were already present by Day 21 , the earliest day on which the animal was tested.

\section{Discussion}

Many large mammals have already become extinct in the wild and survive only under managed breeding programmes in zoological parks and wildlife reserves. It is clear from this study that the techniques of embryo collection from Przewalski's horse and zebra mares, under short-term reversible sedation, and the extra-specific transfer of the embryos to domestic mare recipients, could be used to aid the fecundity of these and other exotic equids. Our results indicate that it is reasonable to expect to be able to collect 6-8 embryos from a Przewalski's horse or zebra mare in a breeding season from which $2-4$ foals of each species could be born after embryo transfer to domestic recipients. This study is the first to demonstrate that Przewalski's horse foals can be born using embryo transfer techniques and our zebra foals follow the birth of a Grant's zebra foal in Kentucky in 1984 after transfer to a domestic Quarterhorse recipient mare (Bennett \& Foster, 1985).

The initial pregnancy rates for Przewalski's horse embryos in horses, and zebra embryos in horses, were high and are similar to those reported for reciprocal extra-species embryo transfer between horses and donkeys (Allen, 1982) and for normal intra-specific transfers in horses (Douglas, 1982; Juliano et al., 1985). The possible causes of the pregnancy failures that occurred during the first 100 days of gestation remain unclear.

It was surprising to find that fewer zebra-in-donkey pregnancies were established compared to zebra-in-horse pregnancies and that 2 of the 3 zebra-in-horse pregnancies survived to term. Initially, it was expected that donkeys would prove to be more suitable than domestic horses as recipients for zebra embryos because of their closer evolutionary relationship to the zebra (Zeuner, 1963). In addition, earlier experiments had demonstrated that transfer of horse embryos to donkeys results in normal endometrial cup development and the survival of the majority of horse foals to term, whereas reciprocal transfer of donkey embryos to horses is followed by a complete failure of endometrial cup development at Day 36 and the subsequent failure of the majority of these extraspecific conceptuses between Days 80 and 100 of gestation (Allen, 1982). More recent experiments have demonstrated that a marked increase in the survival rate of donkey-in-horse pregnancies can be achieved by actively immunizing the recipient mares against parental or unrelated donkey lymphocytes during early gestation, but not by administering large doses of partly purified horse CG (Allen et al., 1987).

While it was not possible to determine accurately the cross-reactivity of the anti-horse CG serum used in the haemagglutination-inhibition assay against purified extracts of Przewalski's horse $\mathrm{CG}$ or zebra $\mathrm{CG}$, we are confident, for the following reasons, that the assay method gave a reasonably accurate reflection of the rate of $\mathrm{CG}$ secretion, and hence the amount and duration of endometrial cup development, in the different types of extra-species equine pregnancy examined in the study: (a) pregnant zebra serum gave a parallel dose-response curve to pregnant horse serum in the assay; (b) mares carrying Przewalski's horse conceptuses showed CG profiles of similar variability and peak concentrations to mares carrying intra-species horse conceptuses (Allen, 1969b); (c) donkeys carrying zebra conceptuses and zebra intra-species zebra conceptuses showed peak serum CG concentrations similar to those measured in donkeys carrying intra-species donkey conceptuses (Allen, 1975). The very brief period of gestation (Day 36-53) when CG was detectable in the serum of all 3 mares carrying zebra conceptuses and the premature disappearance of CG activity from the serum of both donkeys carrying zebra conceptuses and mares carrying Przewalski's horse conceptuses suggests that development of a strong maternal cell-mediated cytotoxic reaction against xenogeneic 
endometrial cup cells in both species of surrogate mother. Furthermore, the extremely low levels of CG activity measured in the mares carrying zebra conceptuses suggest that only very small amounts of zebra chorionic girdle tissue had successfully invaded the surrogate horse endometrium around Day 36 in an attempt to form CG-secreting endometrial cups. The increased cell-mediated response to the endometrial cups would be expected in view of the earlier findings of a marked increase in this reaction in mares carrying inter-species mule conceptuses (Allen, 1975). The minimal cup development in the horse carrying zebra conceptuses is likewise similar to the situation in horses carrying donkey conceptuses in which endometrial cups are absent due to complete failure of the donkey chorionic girdle to invade the surrogate maternal endometrium (Allen, 1982). Clearly, the uterine environment exerts a profound influence on both the development and invasive properties of the equine chorionic girdle.

Despite the various small amounts of endometrial cup development in the mares carrying zebra conceptuses, sufficient tissue did invade to stimulate the generation of endometrial lymphocytotoxic antibodies in all 3 animals. It has been proposed (Allen, 1982) that the development of the endometrial cups has an important immunological function in the maintenance of equine pregnancy. It seems likely that the antigenic stimulus provided at Day 36 by the invasion of the specialized chorionic girdle cells to form the cups (Allen et al., 1973) is necessary to stimulate the maternal immune system to mount an immunoprotective response towards the allogeneic or xenogeneic fetus. The development of suppressor lymphocyte populations (Clark et al., 1984) and/or blocking (enhancing) antibodies (Voisin, 1980) may be involved in this immunoprotective reaction at the feto-maternal interface.

The gestation period in zebras is generally $25-40$ days longer than in the domestic horse (Wackernagel, 1965). Our finding that gestation length in the two zebra-in-horse pregnancies was similarly prolonged agrees with the concept that it is the fetus, through maturation of its hypothalamo-pituitary-adrenal axis, which controls the onset of parturition (Liggins, 1979). Further support of this concept comes from the finding that, in pregnancies established by reciprocal embryo transfer between Bos indicus and Bos taurus, two species of cattle with different gestation lengths, the genotype of the fetus, not the recipient, influenced the gestation length (Summers et al., 1983).

We conclude that extra-specific embryo transfer can be a useful aid to breeding exotic equids in captivity. The technique could be used to increase the size of a herd of exotic equids although a more likely application would be to increase the number of offspring from scarce genetic lines involving a particular mare and stallion. The development of cryopreservation techniques for equine embryos (Czlonkowska et al., 1985) could broaden the scope of the method by facilitating the intra- and inter-continental movement of genetic material between zoos and wildlife reserves.

We thank the keepers and veterinary science staff of London Zoo for their co-operation and technical assistance. The experiments were supported financially by the Nuffield Foundation, the Horserace Betting Levy Board, the Thoroughbred Breeders' Association and an MRC/AFRC Programme Grant (to Professor J. P. Hearn) at the Institute of Zoology.

\section{References}

Aggarwal, B.B., Farmer, S.W., Papkoff, H., Stewart, F. \& Allen, W.R. (1980) Purification and secretion of donkey chorionic gonadotrophin. J. Endocr. 85, 449-455.

Allen, W.R. (1969a) A quantitative immunological assay for Pregnant Mare Serum Gonadotrophin. J. Endocr. 43, $581-591$.

Allen, W.R. (1969b) The immunological measurement of Pregnant Mare Serum Gonadotrophin. J. Endocr. 43, 593-598.

Allen, W.R. (1975) The influence of fetal genotype upon endometrial cup development and PMSG and progestagen production in equids, J. Reprod. Fert., Suppl. 23, 405-413.

Allen, W.R. (1982) Immunological aspects of the endometrial cup reaction and the effect of xenogeneic pregnancy in horses and donkeys. J. Reprod. Fert., Suppl. 31, 57-94.

Allen, W.R., Hamilton, D.W. \& Moor, R.M. (1973) The origin of equine endometrial cups. II. Invasion of the endometrium by trophoblast. Anat. Rec. 117, 475-501. 
Allen, W.R., Kydd, J.H. \& Antczak, D.F. (1987) Maternal immunological response to the trophoblast in xenogenic equine pregnancy. In Immunoregulation and Fetal Survival (in press). Eds T. Gill \& T. H. Wegmann. Oxford University Press, Oxford.

Bangham, D.F. \& Woodward, P.M. (1966) The second international standard for serum gonadotrophin. Bull. Wld Hlth Org. 35, 761-773.

Bennett, S.D. \& Foster, W.R. (1985) Successful transfer of a zebra embryo to a domestic horse. Equine vet. $J$., Suppl. 3, 78-79.

Betteridge, K.J., Eaglesome, M., Mitchell, D., Flood, P.F. \& Beriault, R. (1982) Development of horse embryos up to twenty days after ovulation: observations on fresh specimens. J. Anat. 135, 191-209.

Billingham, R.F. \& Head, J.R. (1981) Current trends in reproductive immunology: an overview. J. Reprod. Immunol. 3, 253-266.

Bright, S., Antczak, D.F. \& Ricketts, S. (1978) Studies on equine leukocyte antigens. In Equine Infectious Diseases $I X$, pp. 229-236. Eds J. T. Bryant \& H. Gerber. Veterinary Publications Inc., Princeton.

Clark, D.A., Slapsys, R., Croy, B.A., Krcek, J. \& Rossant, J. (1984) Local active suppression by suppressor cells in the decidua: a review. Am. J. Reprod. Immunol. 5, $78-83$.

Czlonkowska, M., Boyle, M.S. \& Allen, W.R. (1985) Deep freezing of horse embryos. J. Reprod. Fert. 75, 485-490.

Douglas, R.H. (1982) Some aspects of equine embryo transfer. J. Reprod. Fert., Suppl. 32, 405-408.

Durrant, B. \& Benirschke, K. (1981) Embryo transfer in exotic animals. Theriogenology 15, 77-83.

Gray, A.P. (1972) Mammalian Hybrids, 2nd edn, pp. 94-113. Commonwealth Agricultural Bureaux, Slough.

Juliano, M.F., Squires, E.L. \& Cook, V.M. (1985) Effect of age of equine embryos and method of transfer on pregnancy rate. J. Anim. Sci. 60, 258-263.

King, J.M. (1965) Comparative aspects of reproduction in Equidae. Ph.D. thesis, University of Cambridge.

Kydd, J., Miller, J., Antczak, D.F. \& Allen, W.R. (1982) Maternal anti-fetal cytotoxic antibody responses of equids during pregnancy. J. Reprod. Fert., Suppl. 32, 361-369.

Kydd, J., Allen, W.R., Boyle, M.S., Shephard, A. \& Summers, P.M. (1985) Successful transfer of exotic equine embryos to domestic horses and donkeys. Equine vet. J., Suppl. 3, 80-84.

Liggins, G.C. (1979) Initiation of parturition. Br. med. Bull. 35, 145-150.

Newcomb, R., Booth, W.D. \& Rowson, L.E.A. (1977) The effect of oxytocin treatment on the levels of prostaglandin F in the blood of heifers. J. Reprod. Fert. 49, 17-24.

Short, R.V. (1969) Implantation and the maternal recognition of pregnancy. In Foetal Autonomy (Ciba Fdn Symp.), pp. 2-26. Eds G. E. W. Wolstenholme \& M. O'Connor. J. \& A. Churchill, London.

Short, R.V. (1975) The evolution of the horse. J. Reprod. Fert., Suppl. 23, 1-6.

Simpson, D.J., Greenwood, R.E.S., Ricketts, S.W., Rossdale, P.D., Sanderson, M. \& Allen, W.R. (1982) Use of ultrasound echography for early diagnosis of single and twin pregnancy in the mare. J. Reprod. Fert., Suppl. 32, 431-439.

Stover, J. \& Westrom, W.K. (1984) Reproductive studies unit of the New York Zoological Society. Zoo Biology 3, 335-341.

Summers, P.M., Shelton, J.N. \& Edwards, J. (1983) The production of mixed-species Bos taurus-Bos indicus twin calves. Anim. Reprod. Sci. 6, 7989.

Urwin, V.E. \& Allen, W.R. (1982) Pituitary and chorionic gonadotrophic control of ovarian function during early pregnancy in equids. J. Reprod. Fert., Suppl. 32, 373-381.

Voisin, G.A. (1980) Role of antibody classes in the regulatory facilitation reaction. Immunol. Rev. 49, 3-59.

Wackernagel, H. (1965) Grant's zebra, Equus burchellis boehmi, at Basle Zoo-a contribution to breeding biology. Int. Zoo $\mathrm{Yb}$. 5, 38-41.

Zeuner, F.E. (1963) A History of Domesticated Animals, p. 300 . Hutchinson, London.

Received 7 May 1986 